\title{
Hyperfibrinogenaemia and hyperviscosity in sickle-cell crisis
}

\author{
S. G. N. RICHARDSON, G. R. BREEZE, AND J. STUART1 \\ From the Department of Haematology, Queen Elizabeth Hospital and The Children's Hospital, Birmingham
}

SYNOPSIS Plasma fibrinogen concentration and whole-blood viscosity, the latter measured at two shear rates (23 and $230 \mathrm{sec}^{-1}$ ), were estimated during eight episodes of sickle-cell crisis and com- $\bar{\omega}$ pared with values in 26 sickle-cell anaemia patients who were not in crisis. Painful crisis was associated with a significant increase in both plasma fibrinogen and whole-blood viscosity. Increased fibrinogen-erythrocyte interaction in vivo may be a significant contributory factor to raising blood. viscosity and precipitating vaso-occlusive crisis in sickle-cell disease.

The viscosity of whole blood is largely determined by the number of red cells (haematocrit) and by the deformability of individual red cells. Viscosity is also influenced by fibrinogen and other proteins which induce red-cell aggregation by protein-cell membrane interaction (Chien et al, 1967; Replogle et al, 1967; Rosenblum, 1969), and this is particularly important at low flow rates as in large veins, venules, and the microcirculation.

The role of hyperfibrinogenaemia in vivo in increasing viscosity and leading to vaso-occlusive crisis in sickle-cell disease is not well defined although it has been suggested that the rise in fibrinogen during pregnancy and in acute infection may play a major role in precipitating crisis (Harris and Murphy, 1973). A study has therefore been made of plasma fibrinogen and whole-blood viscosity in children with sickle-cell disease to determine the changes which occur in vaso-occlusive crisis.

\section{Patients and methods}

Blood was taken from 26 asymptomatic children (aged 3-16 years) attending a haematology outpatient clinic, of whom 18 had homozygous sicklecell anaemia (SS) and eight had sickle-cell $\beta$ thalassaemia. Blood specimens were also obtained from eight children (seven with SS) during admission for painful crisis. Routine bacteriological studies included blood, throat, and mid-stream urine cultures and the cytocentrifuge-NBT score (Gordon et al, 1975).

\footnotetext{
${ }^{1}$ Reprint requests to Dr J. Stuart, Department of Haematology, Queen Elizabeth Hospital, Birmingham B15 2TH
}

Received for publication 4 March 1976

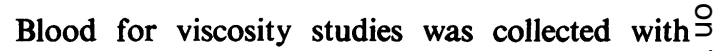
minimal venous stasis into solid EDTA $(1.8 \mathrm{mg} / \mathrm{ml})$, $\vec{\circ}$ with thorough mixing to avoid microclot formation, and measured within four hours of collection. 음 Viscosity was measured using a Wells-Brookfield $\stackrel{\Phi}{-}$ cone-plate microviscometer incorporating a $1.565^{\circ} \overrightarrow{0}$ cone. Measurements were made at $37^{\circ} \mathrm{C}$ and at trgo shear rates corresponding to estimated physiologifal shear rates in veins and vessels of capillary diametrir $\left(23 \mathrm{sec}^{-1}\right)$ and large arteries $\left(230 \mathrm{sec}^{-1}\right)$. Before viscosity measurements were made the blood was bubble oxygenated for 5 minutes and then mixed $\frac{\mathrm{O}}{\circ}$ for 10 minutes on a roller-type blood mixer.

When the temperature of the microviscometer $\overrightarrow{\overrightarrow{0}}$ sample-cup had reached $37^{\circ} \mathrm{C}, 0.8 \mathrm{ml}$ of blood was introduced into the cup and the specimen was sheared at $23 \mathrm{sec}^{-1}$ for 3 minutes to allow: stabilization before a reading was taken. The sample was then sheared at the same rate for a further $2_{0}^{\circ}$ minutes to give a second reading. The instrument was cleaned, a second $0.8 \mathrm{ml}$ aliquot of the samed blood sample was introduced, and a further two readings were taken at $23 \mathrm{sec}^{-1}$. The value obtainedo from the mean of the four readings was adjusted to a standard haematocrit of 0.45 and expressed in centipoises (cps). At $230 \mathrm{sec}^{-1}$ the viscometer is more accurate and two readings only, on a furthero aliquot, were taken.

The relationship between whole-blood viscosity (at $23 \mathrm{sec}^{-1}$ and $230 \mathrm{sec}^{-1}$ ) and fibrinogen concentra- $\omega$ tion was studied by adding known amounts of fibrinogen (Kabi) to washed normal (AA) red cells resuspended in autologous heparinized serum.

Fibrinogen was studied according to Ellis and Stransky (1961) and packed cell volume (PCV) byo a microhaematocrit method. Statistical significancep was determined using Student's $t$ test. 


\section{Results}

The effect of sickle-cell crisis compared with the asymptomatic state is shown in table I. Painful crisis was associated with a significantly higher mean whole-blood viscosity at shear rates of both $23 \mathrm{sec}^{-1}$ $(P<0.02)$ and $230 \sec ^{-1}(P<0.02)$, and with a significantly higher mean plasma fibrinogen $(\mathrm{P}<$ 0.01 ). There was no significant difference in PCV or NBT score.

Five of the eight patients in crisis were studied again when asymptomatic to act as their own controls (table II). Each crisis episode was associated with an increase in blood viscosity and fibrinogen with the exception of patient 3 . This patient had a less severe crisis episode, with only one localized area of pain and tenderness, compared with the other petients.

Detectable bacterial infection was present in one patient only, who had bronchopneumonia. The seven other patients in crisis were febrile on admission, but there was no clinical evidence of infection, bacteriological cultures did not yield significant growth, and the temperature settled without antibiotics. Cytocentrifuge-NBT scores remained within the normal range of $0-18 \%$ (Gordon et al, 1975).
There were no other apparent crisis-precipitating factors in these children and they were not dehydrated on admission.

An approximately linear relationship was found in vitro between blood viscosity and the amount of added fibrinogen within the range $2 \cdot 0-10 \cdot 0 \mathrm{~g} / \mathrm{l}$ (figure). The mean increase in viscosity at $230 \mathrm{sec}^{-1}$ found in patients during crisis $(0.42 \mathrm{cps}$; table I) was no greater than the increase anticipated from a rise in mean fibrinogen from 2.29 to $3.81 \mathrm{~g} / \mathrm{l}$. At $23 \mathrm{sec}^{-1}$, however, the mean increase observed in the patients in crisis $(0.8 \mathrm{cps})$ was almost twice that anticipated $(0.45 \mathrm{cps})$.

\section{Discussion}

A significant increase in the viscosity of oxygenated whole-blood at physiological shear rate has been found in children during painful sickle-cell crisis. This result is in agreement with previous in vitro experimental studies using oxygenated (Dintenfass, 1964; Chien et al, 1970) and deoxygenated (Ham and Castle, 1940; Harris et al, 1956; Charache and Conley, 1964; Dintenfass, 1964) blood which had previously been taken from sickle-cell patients in the steady state. These previous studies showed

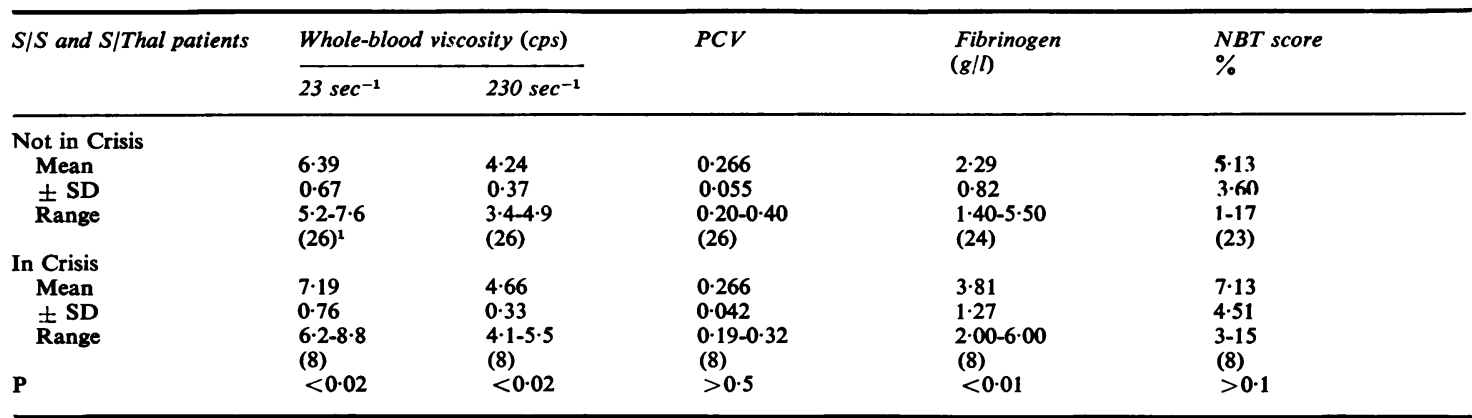

Table I Effect of painful crisis on viscosity, PCV, fibrinogen, and NBT score in $S / S$ and $S / T h a l$ patients.

${ }^{2}$ Number of episodes studied shown in parentheses

\begin{tabular}{|c|c|c|c|c|c|c|}
\hline \multirow{3}{*}{ Patient } & \multicolumn{3}{|l|}{ In Crisis } & \multicolumn{3}{|c|}{ Out of Crisis } \\
\hline & \multicolumn{2}{|c|}{ Whole-blood viscosity (cps) } & \multirow{2}{*}{$\begin{array}{l}\text { Fibrinogen } \\
(\mathrm{g} / \mathrm{l})\end{array}$} & \multicolumn{2}{|c|}{ Whole-blood viscosity (cps) } & \multirow{2}{*}{$\begin{array}{l}\text { Fibrinogen } \\
(\mathrm{g} / \mathrm{l})\end{array}$} \\
\hline & $23 \sec ^{-1}$ & $230 \mathrm{sec}^{-1}$ & & $23 \mathrm{sec}^{-1}$ & $230 \mathrm{sec}^{-1}$ & \\
\hline $\begin{array}{l}1 \\
2 \\
3 \\
4 \\
51\end{array}$ & $\begin{array}{l}7.0 \\
8.8 \\
6.2 \\
7.0 \\
7.5\end{array}$ & $\begin{array}{l}4.8 \\
5.5 \\
4.1 \\
4.6 \\
4.7\end{array}$ & $\begin{array}{l}3 \cdot 5 \\
5.0 \\
2.0 \\
3 \cdot 2 \\
6.0\end{array}$ & $\begin{array}{l}6.8 \\
7.5 \\
7.0 \\
5.8 \\
6.0\end{array}$ & $\begin{array}{l}4 \cdot 6 \\
4 \cdot 9 \\
4 \cdot 1 \\
4 \cdot 0 \\
4 \cdot 1\end{array}$ & $\begin{array}{l}1.5 \\
2.6 \\
1.9 \\
2.45 \\
1.7\end{array}$ \\
\hline
\end{tabular}

Table II Blood viscosity and plasma fibrinogen values in five patients studied in, and out of, crisis

'Patient 5 studied on two occasions 


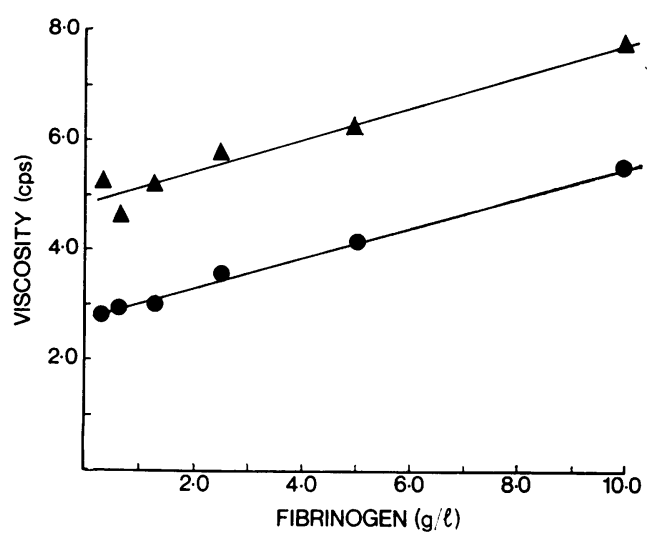

Figure Relationship between whole-blood viscosity (corrected to haematocrit of 0.45 ) and plasma fibrinogen as determined at shear rates of $23 \mathrm{sec}^{-1}$ ( $\Delta$ ) and $230 \sec ^{-1}(O)$.

increased viscosity for SS cells compared with control (AA) cells.

The hyperviscosity of sickle-cell crisis in the present clinical study was not the result of increased haematocrit, a major determinant of whole-blood viscosity, and the viscosity readings were in any case subsequently adjusted to a standard haematocrit of 0.45. Chien et al (1970) demonstrated that the increased viscosity of oxygenated SS cells, compared with control (AA) cells, was predominantly due to the irreversibly sickled cells (ISC) which have increased internal viscosity and reduced membrane deformability. Our patient samples, which had been oxygenated, contained an insignificant number of ISC, possibly due to residual splenic function (Serjeant et al, 1969) in our younger patients.

It is possible that the hyperfibrinogenaemia observed during crisis (mean rise $1.52 \mathrm{~g} / \mathrm{l}$ ) was at least partly responsible for the increase in wholeblood viscosity since cell-protein interaction at low flow-rates induces red-cell aggregation which greatly increases the yield stress (Klug et al, 1974). A causal relationship between hyperfibrinogenaemia and hyperviscosity has similarly been proposed by Dormandy et al (1973a) for patients with intermittent claudication in whom hyperviscosity seemed to be the determining cause of claudication (Dormandy et al, 1973b). Homozygous sickle-cell patients in the steady state do not show an increase in fibrinogen concentration compared with healthy controls (Leslie et al, 1975) but a significant increase in fibrinogen during crisis has now been observed in the present study, in an earlier report from this centre (Gordon et al, 1974) and by Walsh et al (1973). The rise in fibrinogen did not appear to be caused by bacterial infection (Goldenfarb et al,
1970; Green et al, 1970) in any of these three studiesa The explanation is therefore unknown, and althoug an earlier study did not show evidence of disseminated, as opposed to localized, intravascular coagu $\overrightarrow{\bar{F}}$ lation in painful crisis (Gordon et al, 1974), a similaf study of coagulation factor levels carried ouf serially before, during, and after vaso-occlusiv crisis would be of value. Bacteriological, an $\bar{\Phi}$ particularly virological, studies should be performed् in parallel.

It is therefore suggested that the hyperfibrino $\vec{e}$ genaemia of sickle-cell crisis contributes to red ceit sludging and increased whole-blood viscosity at the onset of crisis. The increase in viscosity was foun to be approximately double at low shear rate, where fibrinogen has a greater effect (Chien et al, 1967). and since circulating ISC also exert a greater effect at low shear rate (Chien et al, 1970) they are likeligo to have a substantial additive effect in areas of the circulation characterized by low shear and higle viscosity, such as the leg veins. Superficial venous blood of the lower leg has a temperature of aroun\$ $30^{\circ} \mathrm{C}$ (Rubenstein and Lack, 1959) and since the high viscosity of sickle-cell blood at $37^{\circ} \mathrm{C}$ is furthe increased by a temperature drop to $30^{\circ} \mathrm{C}$ (Rubenstein 1961), the leg veins are a potentially important site of vascular sludging and the initiation of sickliogg. This temperature differential is likely to becomg greater during exposure to cold, and an association between crisis frequency and seasonal environmenta

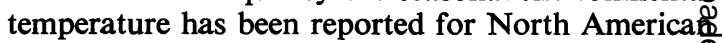
(Amjad et al, 1974) and Jamaican (Redwood et a\& 1976) patients. Vascular sludging in the superficiaft leg veins may also be associated with local activas tion of coagulation-fibrinolysis resulting in the formation of cryofibrinogen which could furthex. increase viscosity as suggested for patients wit generalized hypothermia (Goodall et al, 1975).

We are indebted to the Central Birmingham Health District Trust Funds for financial support. Detaiß from this study were presented to the British Societry for Haematology, London 1976.

\section{References}

Amjad, H., Bannerman, R. M., and Judisch, J. M. (1974\%? Sickling pain and season. (Letter). Brit. med. J., 2, 54 . N Charache, S. and Conley, C. L. (1964). Rate of sickling of red cells during deoxygenation of blood from persons witbu various sickling disorders. Blood, 24, 25-48.

Chien, S., Usami, S., and Bertles, J. F. (1970). Abnorma rheology of oxygenated blood in sickle cell anemia J. clin. Invest., 49, 623-634.

Chien, S., Usami, S., Dellenback, R. J., Gregersen, M. I? Nanninga, L. B., and Guest, M. M. (1967). Blood viscov sity: Influence of erythrocyte aggregation. Science, $15 \overline{\mathrm{a}}$ 829-831.

Dintenfass, L. (1964). Rheology of packed red blood celه্ه 
containing hemoglobins A-A, S-A, and S-S. J. Lab. clin. Med., 64, 594-600.

Dormandy, J. A., Hoare, E., Colley, J., Arrowsmith, D. E., and Dormandy, T. L. (1973a). Clinical, haemodynamic, rheological, and biochemical findings in 126 patients with intermittent claudication. Brit. med. J., 4, 576-581.

Dormandy,J. A., Hoare, E., Khattab, A. H., Arrowsmith, D. E., and Dormandy, T. L. (1973b). Prognostic significance of rheological and biochemical findings in patients with intermittent claudication. Brit. med. J., 4, 581-583.

Ellis, B. C. and Stransky, A. (1961). A quick and accurate method for the determination of fibrinogen in plasma. J. Lab. clin. Med., 58, 477-488.

Goldenfarb, P. B., Zucker, S., Corrigan, J. J., Jr., and Cathey, M. H. (1970). The coagulation mechanism in acute bacterial infection. Brit. J. Haemat., 18, 643-652.

Goodall, H. B., Todd, A. S., Maclean, D., Henderson, R., and King, J. F. (1975). Cyrofibrinogenaemia and activation of the coagulation/lysis systems in accidental hypothermia of the elderly. (Abstr.) J. clin. Path., 28, 758.

Gordon, P. A., Breeze, G. R., Mann, J. R., and Stuart, J. (1974). Coagulation fibrinolysis in sickle-cell disease. J. clin. Path., 27, 485-489.

Gordon, P. A., Stuart, J., Lee, T. R., Breeze, G. R., and Pugh, R. N. H. (1975). The cytocentrifuge NBT test. J. clin. Path., 28, 674-679.

Green, D., Kwaan, H. C., and Ruiz, G. (1970). Impaired fibrinolysis in sickle cell disease. Relation to crisis and infection. Thrombos. Diathes. haemorrh. (Stuttg.), 24, 10-16.

Ham, T. H. and Castle, W. B. (1940). Relation of increased hypotonic fragility and of erythrostasis to the mechanism of hemolysis in certain anemias. Trans. Ass. Amer. Phys., 55, 127-132.

Harris, J. W., Brewster, H. H., Ham, T. H., and Castle, W. B. (1956). Studies on the destruction of red blood cells.
X. The biophysics and biology of sickle-cell disease. Arch. intern. Med., 97, 145-168.

Harris, J. W. and Murphy, J. R. (1973). Life cycle of sicklecells in the circulation. In Sickle-Cell Disease: Diagnosis, Management, Education and Research, edited by $\mathrm{H}$. Abramson, J. F. Bertles, and D. L. Wethers, p. 164. Mosby, St. Louis.

Klug, P. P., Lessin, L. S., and Radice, P. (1974). Rheological aspects of sickle cell disease. Arch. intern. Med., 133, 577-590.

Leslie, J., Langler, D., Serjeant, G. R., Serjeant, B. E., Desai, P., and Gordon, Y. B. (1975). Coagulation changes during the steady state in homozygous sickle-cell disease in Jamaica. Brit. J. Haemat., 30, 159-166.

Redwood, A. M., Williams, E. M., Desai, P., and Serjeant, G. R. (1976). Climate and painful crisis of sickle-cell disease in Jamaica. Brit. med, J., 1, 66-68.

Replogle, R. L., Meiselman, H. J., and Merrill, E. W. (1967). Clinical implications of blood rheology studies. Circulation, 36, 148-160.

Rosenblum, W. I. (1969). "Viscosity-plus" effect in whole blood at high shear rates. Nature (Lond.), 221, 365-366.

Rubenstein, E. (1961). Studies on the relationship of temperature to sickle cell anemia. Amer. J. Med., 30, 95-98.

Rubenstein, E. and Lack, A. (1959). The temperature of venous blood in the extremities and its relationship to the clotting process. Clin. Res., 7, 61-62.

Serjeant, G. R. Serjeant, B. E., and Milner, P. F. (1969). The irreversibly sickled cell; a determinant of haemolysis in sickle cell anaemia. Brit. J. Haemat., 17, 527-533.

Walsh, R. T., Lusher, J. M., and Barnhart, M. I. (1973). Coagulation and fibrinolysis studies in sickle cell anemia. In Sickle Cell Disease, edited by E. F. Mammen, G. F. Anderson, and M. I. Barnhart, pp. 271-2.79. Schattauer, Stuttgart. 